Publisher homepage: www.universepg.com, ISSN: 2707-4641 (Online) \& 2707-4633 (Print) https://doi.org/10.34104/ijma.020.0960104

International Journal of Management and Accounting

Journal homepage: www.universepg.com/journal/ijma

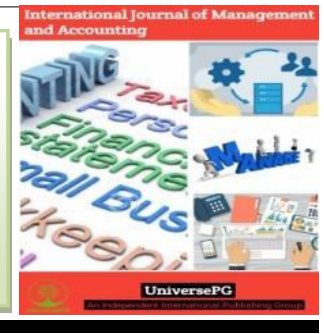

\title{
Reviewing YouTube as a Compelling Tool for the Promotion of Tourism
}

\author{
Sanjoy Kumar Roy ${ }^{1}$, Mst. Rinu Fatema ${ }^{1}$, Md. Jamsedul Islam ${ }^{1} *$, and Md. Nazmul Huda ${ }^{1}$ \\ ${ }^{1}$ Department of Tourism \& Hospitality Management, Noakhali Science \& Technology University (NSTU), Noakhali-3814, \\ Chittagong, Bangladesh. \\ *Correspondence: mji.thm.nstu@gmail.com (Md. Jamsedul Islam, Lecturer, Department of Tourism \& Hospitality \\ Management, NSTU, Noakhali, Bangladesh).
}

\begin{abstract}
YouTube has been recognized as one of the influential platforms as a social medium, allowing people across the world to express their thoughts and ideas through sharing videos. The travel-related videos have produced the second-highest searched results from its users of this giant social media in recent years. This study is basically based on an exploratory approach to discover the beneficial uses of YouTube as a promotional platform for travel businesses. To gain insight into the projection, information from secondary sources is investigated. A good quality video with logical contents containing the real scenario of travel products can be placed on YouTube to attract attention from a mass population in a very short time. The presentation of the information in this study, collected from established sources will construct an understanding of the online promotional tool and YouTube as one of them in influencing potential travelers. It will also provide an idea about the effectiveness of YouTube as a promotional tool for business through the revenue generation it has been earning from advertising. Bangladesh tourism and its stakeholders can take advantage of this online stage to make people aware of their products and services.
\end{abstract}

Keywords: Tourism, YouTube, Online platforms, Promotion, Tourism products, Marketing and Travel.

\section{INTRODUCTION:}

While the world has been experiencing an increment in the number of visitors in the recent time, the technological sufficiency of travel marketers leaving the business world to a complete new room in attracting the potential travelers' attentions and eventually influence their decision making. The fastest growing industry has encountered a consecutive growth for the last ten years where the new number of internal tourists' arrival reached at 1.9 billion globally in 2019, an increase of 4 percent from the last year (UNWTO, 2020). The opportunities from digitization, innovation, societal formation and enhancement in accessibility have called for the introduction of sophisticated strategies to place this sector as a sustain- able one while focusing on the quality rather than the quantity. The idea of becoming travelers, surpassing the traditional tourist recognition among the potential markets has pushed the industry holders into a challenging situation in placing their tourism products combining both the experience and authenticity where it emerges as a result of new destination arrivals, changes in consumer profiles and online travel facilities (Hossain et al., 2020; Atrevia, 2019).

The increasing competition among the destinations has initiated thoughts among the tourism marketers to bring changes in business strategies to such a phase where the goal of increased customer awareness, promotion of brands and economic outcomes can be attained (Picincu, 2018). The government of many 
nations has provided emphasis on the marketing of their destinations to promote their tourism products as well as enhance their economic progressions. The new era of business arising from the technological boom has made it unthinkable to promote and distribute tourism products without the contemplation of distribution channels based on technology such as the internet (UNWTO, 1999). The pattern of uses among the potential travelers regarding technological products and information based platforms, has become one of the major examining factors for the tourism service providers to understand the emerging interactive technologies and other internet based gadgets to capitalize them in informing the markets about their products and ultimately grasp the targeted markets. The internet and its features in terms of business promotion such as social media, web presence, blogging, search engine optimization, email marketing and online advertising have shown the best way to ensure the enhancement of communication and to let the markets know about the contents of the service providers (Techroadians, 2020).

The popular marketing model known as AIDA (Awareness, Interest, Desire, and Action) confronted an achievement in dealing with its components through digital marketing where the browsers sets the interest making people aware about different destinations and once the desire is formed, let the potential markets to take action by booking and buying their trips (Pitanatri, 2016). The growth of internet users worldwide has created a newer platform for travel businesses to make aware their potential customers through video content sharing about their products using YouTube, a social media platform with a goal to stimulate the market in the most cost effective way. As an online marketing platform, YouTube has already accomplished the goal of convincing projected travel markets and it can be seen from a statistics provided by Goggle.com that the YouTube travel searches has reached at around 88 percent regarding destinations, attractions and other travel ideas in 2019 (Steeves, 2019). So, digital marketing could be an influential tool for the upcoming travel businesses to interact and engage with their potential consumers in the most effective way.

UniversePG I www.universepg.com

\section{Objectives of the research}

The main objectives to commence this study for the following reasons; one is to review the trends of travel promotion from YouTube and the other is to represent the significance of online travel promotion.

\section{Outcomes of the research}

The technological advancements have ushered us to such a direction where the potential markets of any kind of business are thriving in establishing their marketing strategies to touch their projected benefit lines in recent time. The current research will provide us an in-depth understanding on online marketing for tourism products and deliver evidence on the use of YouTube to introduce this approach for assuring business goal fruition. Bangladesh has been fighting to lay a proper marketing strategy for a long time, even its commencing period in the tourism marathon reveals inefficiency in this occasion. This study will minimally represent the current certainty about promotional strategies in tourism marketing and convey the idea of implementing online marketing tools such as YouTube.

\section{Literature Review}

Today, the business environment forms the way its marketing plan developed prior to the actual action of that particular farm where marketing defines the available selling options and directs the platforms to sell, eventually makes the best out of the opportunities. Tourism businesses cover a wide range of sectors such as accommodation, transportation, food supplies, attractions and entertainment facilities where marketing plays a significant role same as the traditional business having certain dissimilarities in terms of product characteristics. So, the current research has tried to represent the literature regarding tourism marketing, available promotional tools for tourism businesses, online based promotional tools for tourism and of course the role of YouTube as an online promotional to meet the objective of this study.

Tourism marketing - Marketing generally comes in maintaining a relationship which denotes specific actions for a certain business as there are varieties in the marketing process based on the platform, audience and the marketplace. The goal of marketing is not 
beyond the organizational one where the profitability of the firm remains priority ensuring the satisfaction of the target market through providing values (Cohen, 2011; Sardar et al., 2020). Philip Kotler defines marketing as the combin-ation of art and science where he identifies the exploration, creation and delivery of values to satisfy a target market at profit. Tourism marketing basically works with the destination image and branding of the image to the targeted market. As the nature of the tourism product differs from the traditional products, the tourism products require a dedicated plan for individual products. The purpose of tourism marketing majorly involved in attracting visitors to a certain destination where it can be an attraction, a hotel, a entertainment facility or anything that satisfies the needs of the visitors, focusing on the location marketing, activity marketing and corporate marketing as a result (Bhasin, 2019).

Promotional tools for tourism products - Most of the time, the destination management organizations are responsible for promoting a particular destination to the specific potential markets matching the nature of that destination (Gartrell, 1994). But the tourism industry is not confined in destination marketing alone. That is why; promotion is often regarded as a supportive tool for the potential consumers of tourism products to make their buying decisions depending on the information provided by the suppliers of tourism products fading away the information gap between suppliers and potential customers of tourism products (Esu \& Ebitu, 2010). Effective marketing strategy for tourism remains the prerequisite to establish the potential tourism destinations and travel services for specific target markets which calls for the necessity of planning and implementing promotional strategies in destination sites (Hossain, 2020; Morrison, 2013).

A participatory approach is necessary when developing promotional strategies for tourism products combining the respected stakeholders depending on the genre of the product (Bujdoso et al., 2014). Tourism promotional tools basically come in five traditional formats to communicate with potential consumers using advertising, sales promotion, public relation, personal selling and direct marketing (Hasan et al., 2015). Direct marketing communication where the use of mail, telephone, non-personal contact, mail shots, leaflets inserted in the daily magazines are utilized to ensure connectivity with a specific number of customers. Whereas incentives such as discounts on purchase provides an option where the combination of intermediary push and consumer pull offers impulse incentives for the markets (Middleton \& Clarke, 2001). To bring out positivity about a certain product sometimes backed by the sponsorship from the owners of those products while generating awareness about the products and company also (Jobber \& Fahy, 2003). But the digital explosion of information has revealed the idea of digital marketing which avails the opportunities of using different promotional tools such as websites, email, Facebook, Instagram, Twitter, and YouTube to make markets updated about the services offered by the suppliers (Luis, 2019).

Online Based Promotional Tools for Tourism - The changing nature of the business environment continuously leaves the most challenges for the marketing department of a particular organization and influences to set up strategies to adopt the change with the time being. In recent time, the digitization of each facility and the increased dependence on online platforms to avail those facilities by the consumers has created a new stage to interact between the suppliers and consumers. The tourism industry is not out of it and even facing more concern rather than other industries. The introduction of social media, video content sharing and content based marketing has been playing the driving role in creating successful destination marketing tactics (Camille, 2018). There will be some benefit in using an online based platform for tourism business to eradicate the intermediaries and work as an alternative channel for the promotion, communication and distribution of services as well as provide cost effective travel opportunities for the potential travelers (Martorell and Gabriel, 2002). The necessity of creating visuals for products and continuous customer feedback calls for such a phase where the promotional tools can be applied in a collaborative way where necessary to meet the demand of both marketers and consumers. Travel brands can easily make their actions easier in terms of communicating with their service users, specifying potential travelers and engaging with respective stakeholders through a customized application helped by Facebook (Rahman, 2017). 
There are several opportunities available such as online banner, email newsletter, blog, promo video sharing and so on which can be used to promote tourism products with appropriate selection of websites where the targeted customer will visit. The online platform not only ensures the communication between the marketers and prospective buyers but also enables firms to track the effectiveness of their actions through services like Google analytics (Shrigwin, 2019). There are certain facilities provided by the internet to businesses to operate their promotional activities such as Hotjar and Brand24 for monitoring social media insights, content marketing platforms like Canava and Ubersuggest, collaboration tools like Dropbox and so on.

YouTube as a Promotional Tool - The world's second largest search engines on the internet after Goggle, YouTube has become the hub of video sharing platforms where the actual travelers have been sharing their experiences with no influences from the actual service providers and converting the viewers into tourists (Gale, 2017). As the people are spending more time on YouTube, it has become a place to grasp the attention of potential tourists using the video optimization and promote the products to the targeted markets (White, 2019). The concept of video marketing has achieved a thrust with the introduction of YouTube where the main goal is to experience web traffic and let people know about the products. This process seems to be a reality now as statistics shows people all over the world spend 1 billion hours of watching videos on YouTube where it is also found that the age group of 18 to 49 has been spending more time on mobile than cable TV (Brenner, 2018).

A statistics from 2009 which tells the 98.1 million users are sharing their contents, comments at that time which eventually let the business giants to use this tool as tourism marketing tool and attract a large number of audiences (Sofia \& Brian, 2016). This popular video hosting platform could be applied as an advance channel to bring with the new products of tourism where the introduction, brand establishment, promotion, monitoring and on demand service provision of certain products can be achieved.

UniversePG I www.universepg.com

\section{MATERIALS AND METHODS:}

The purpose of the study mainly confined in proving the necessity of YouTube as a promotional tool for business particularly for tourism enterprises and presenting the current trends has been faced by the business environment as result of video marketing through YouTube. The data which are used throughout the study comprise both the quantitative and qualitative nature. The data are based on secondary sources such as blogs, corporate websites, e-journals, articles and ebooks.

The quantitative data which are used in this study collected through verifiable sources. The objectives of the study have been explained in two segments in the whole study where the scope of online promotional tools and their scopes for businesses are discussed in the literature review section. The current trends and the evidence of uses of YouTube in business promotion have been backed by the quantitative data sources in the discussion and analysis section. The limitation of this study is not only involved in absence of data availability but also the specific sources of the data sometimes create confusion in considering those to include in this study ultimately result in a smaller research area.

\section{RESULTS AND DISCUSSION:}

This section focuses on people's behavior and how they are moving towards internet based platforms for communication and other activities related to their personal interests from grocery shopping to travel making. And the trends of online marketing as well as the operations of different varieties are also discussed here with the help of some statistics from secondary sources. The advancements of technology have been providing opportunities for the business world to interact with their targeted markets through internet based platforms. On the demand side, the behavior of people around the world has been changing continuously with the development of available communication gadgets along with platforms. The Internet has become one of the human hubs because of its ability in terms of dealing with services such as increased accessibility, research facilities, innovative learning, business deals and of course socialization of the human race all over the world (Dagostino, 2020). 
The below figure provides us a generic view on the digitization of today's world and how people are indispensable in terms of depending on them to get the best out of it.

Table 1: Global digital snapshots (Kemp, 2020)

\begin{tabular}{|l|l|}
\hline Internet User & 4.54 billion \\
\hline Social Media User & 3.80 billion \\
\hline Mobile Phone User & 5.19 billion \\
\hline Average Internet Usage & 6 hours 3 minutes each day \\
\hline Internet Use via Mobile & $92 \%$ Users of Internet \\
\hline
\end{tabular}

The businesses have been turning to the newer format of marketing to utilize the maximum benefits from digitization. The marketing strategies of firms have also been changed a lot to cope up with the behavioral pattern of potential markets to interact and it can be seen from the recent data on internet advertising trends of 2020 where it has shown, $48.66 \%$ companies have been using online advertising using different platforms.

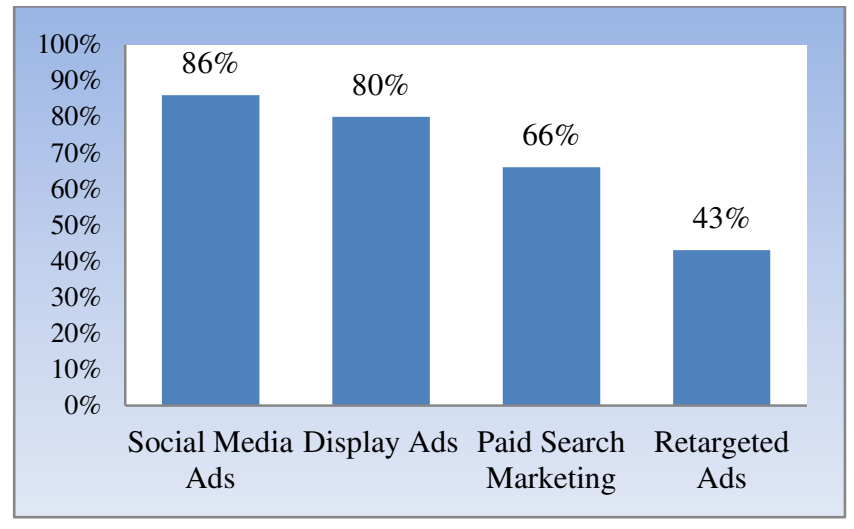

Fig 1: Businesses' share on the online advertising platform (Hostingfacts, 2020).

This scenario has proved that the dependence on the online based marketing tools among the business firms is increasing. Among the available tools for marketing actions run on online stages especially the promotional strategies have been conducted through YouTube in recent time where it ensures effectiveness of advertising as well as the cheapest platform option for the business owners (Forbes, 2018). On the other hand, the YouTube video advertising or YouTube ads has outperformed the Google ads and Facebook Ads for the travel brands where the Google stats also presented about $88 \%$ YouTube searches related to attractions, destinations, point of interests or other travel ideas in 2019 (Tsvetkov, 2019). YouTube has become a platform for communication over a period of time and it has driven the businesses to focus on that particular place to aware their potential market about products and services. The below statistics have shown the impact of YouTube it has been creating on the internet worldwide.

Table 2: YouTube traffic over the Internet (Aslam, 2020)

\begin{tabular}{|l|l|}
\hline Active User & 2 billion \\
\hline Daily Active User & 30 million \\
\hline Videos Watched Daily & 5 billion \\
\hline Mobile YouTube Views Daily & 1 billion \\
\hline YouTube Watch by global Internet population & $95 \%$ \\
\hline Mobile Based YouTube Traffic on Internet & $37 \%$ \\
\hline
\end{tabular}

Such huge online traffic has created an option for the business firm to promote their products and services on that platform. The YouTube earning from advertising alone represents the reliance on it for online promotion.

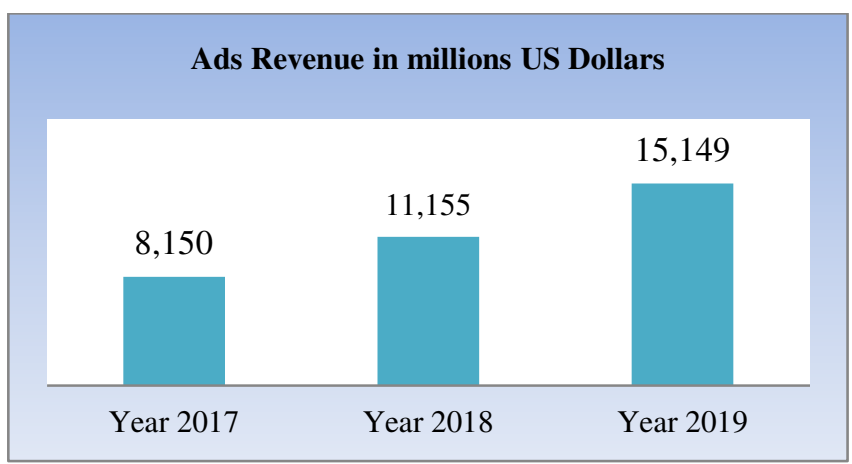

Fig 2: Globally advertising revenues of YouTube from 2017 to 2019 (Statista, 2020).

There are three available options for the travel marketers to use YouTube video ads to convey their destinations' images or brands to the prospective travelers through bumper ads, in-stream ads and discovery ads as people are spending more time on watching videos (Rasmussen, 2017). The digital generation of travelers has come to a point where they spend more time watching video guides for travel plans which is enhancing by $118 \%$ year over year. Taking the example from 2013, data showed how the video content is getting overwhelmed both by the communities and the brands also. 


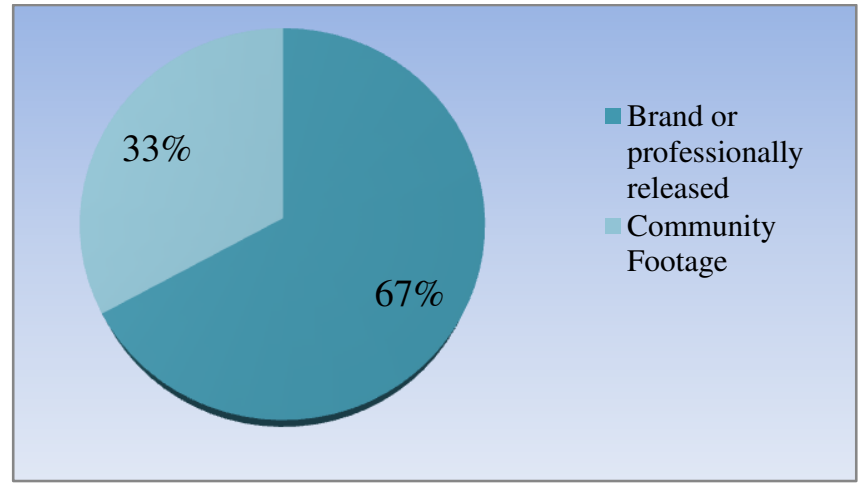

Fig 3: Brands and community created videos over internet (Crowel et al., 2014)

The trends among internet users has experienced changes among travel content seekers who are considered as potential tourists to search for videos on destinations, attractions, hotels and other accommodations facilities, online travel agency services, cruises and other relevant travel information required for travel decisions. The year over year changes along with the particular video search has revealed another picture.

The accumulative view from the above figure constitutes that the travel brands are getting benefits from video content marketing. A stat from YouTube Data has also revealed that about $71 \%$ travel searches on YouTube are based on destination names (Kaushal, 2014).

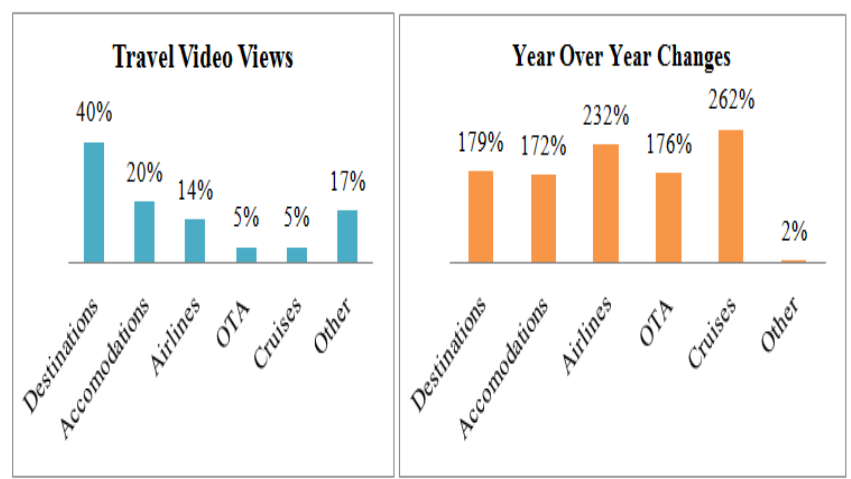

Fig 4: The trends in top search travel videos and changes year over year (Google Data, 2014).

Even the nature of the targeted markets can be easily verifiable that remains a prerequisite for promotional activity. Sneaking into the travel channel subscribers can be an option to exhibit the right target market. The below figure has been provided by YouTube data which can be worked as a preview to dig out more on particular target markets to make marketing decisions.

Table 3: A preview for identifying customers from YouTube (Source: Google Data, 2014)

\begin{tabular}{|l|c|c|}
\hline \multicolumn{1}{|c|}{ Travel Platforms } & Today's Traveler (25-64) & Tomorrow's Traveler (18-24) \\
\hline All Travel Channels Type & $50 \%$ & $38 \%$ \\
\hline Official Brand Channels & $66 \%$ & $27 \%$ \\
\hline Official Networks & $76 \%$ & $19 \%$ \\
\hline Travel Reviews & $64 \%$ & $29 \%$ \\
\hline Travel Footage & $66 \%$ & $24 \%$ \\
\hline Travel vlogs & $43 \%$ & $44 \%$ \\
\hline
\end{tabular}

In selecting the right channels for video advertising or selecting the time can also be attainable through the aid of YouTube algorithms. In traditional promotional strategy, selecting the appropriate channels for the target market is necessary to transfer promotional information to the prospective customers and even the promotion period needs to be specified prior to actual operation. There are various YouTube channels working on travel contents such as travel blogs, travel brand channels, travel footage, review and official travel network. And it is necessary to find out the best option to promote the brand just like taking decisions from the statistics below given by Google Data.

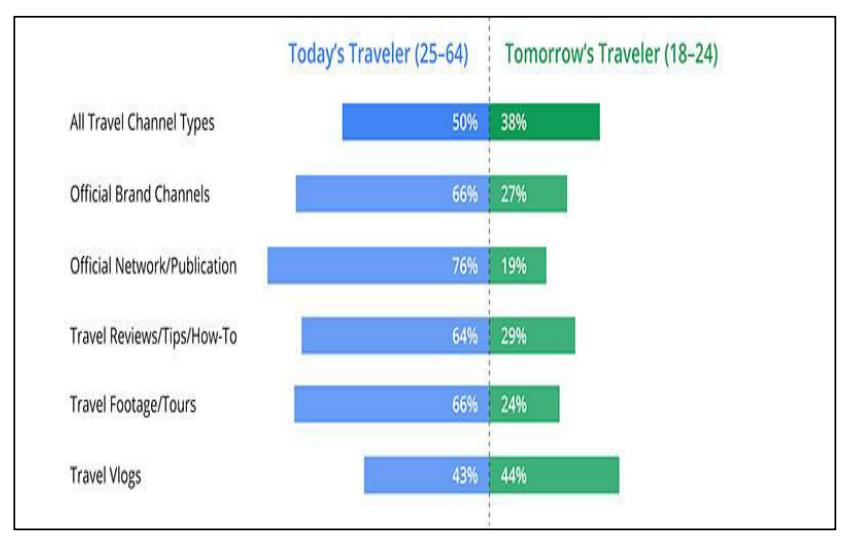

Fig 5: A preview for identifying customers from YouTube (Google Data, 2014). 


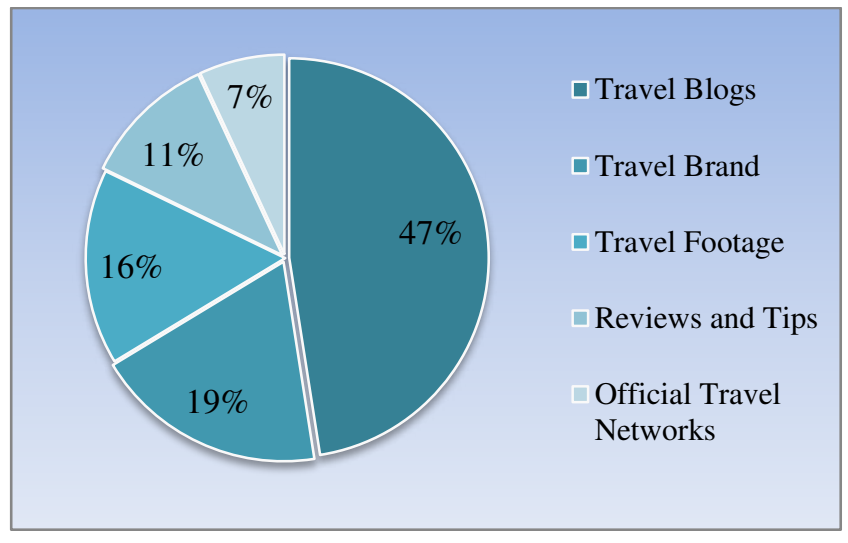

Fig 6: Available travel based channels on YouTube (Goggle Data, 2014).

So, the above discussion has guided us to a point to consider online videos for marketing plans of tourism businesses specifically for the YouTube platform where the fastest growing industry can be a powerful channel to enhance alongside education and learning. YouTube has become a place where people share their experiences creating word of mouth advertising while looking for their next travel decision.

\section{CONCLUSION:}

YouTube offers a place where anyone can express their thoughts, ideas and reviews without any hesitation and therefore, enjoy an environment of maximum democracy. The nature of prospective tourists is not only confined in just buying tourism products, but also they try to project their experiences considering the early visitors' experience. This study will help the stakeholders involved in tourism activities to understand the significance of online promotional platforms and also the role of YouTube in awaking people to make their travel decisions. The data on the trend on people's online surfing behavior reveals why this medium has become influential to reach customers in recent time. On the other hand, the information on YouTube favors the arguments in using it as one of the effective promotional tools. The lack of enough updated and specific data on YouTube travel videos may not satisfy the current trends as it involves cost in getting those data. So, the future studies can be conducted in finding out the capacity of specific videos attracting travelers to take travel services. The recent behavior among the Bangladeshi people on the online platform suggests a new path for the businesses to UniversePG I www.universepg.com divert their promotional channels which can be understood from the example of Facebook as a part of digital marketing.

\section{ACKNOWLEDGEMENT:}

The work has been done with the support of the authors solely of this paper. There was no financial support from any institution to conduct the study.

\section{CONFLICT OF INTERESTS:}

There is no conflict of interest to the publication of this manuscript.

\section{REFERENCES:}

1. Aslam S. (2020). YouTube by the Numbers: Stats, Demographics \& Fun Facts. Accessed on 28 March 2020.

https://www.omnicoreagency.com/youtube-sta $\underline{\text { tistics/ }}$

2. Atrevia, (2019). The new challenges of tourism marketing. Accessed on 27 March 2020.

https://www.atrevia.com/en/news-atrevia/the-n ew-challenges-of-tourism-marketing/

3. Bhasin, H. (2019). What is Tourism Marketing? Concept of Tourism Marketing. Accessed On 27 March 2020.

https://www.marketing91.com/what-is-tourismmarketing/

4. Brenner, M. (2018). Why and how to use YouTube to Promote your business. Accessed On 27 March 2020.

https://marketinginsidergroup.com/content-mar keting/how-to-use-youtube-to-promote-yourbusiness/

5. Bujdoso, Z., Manhas, S. P., Ramjit, David, L. \& Nedelea, A. (2014). Application of Promotion Tools in Hospitality and Tourism Industry and Its Role in Developing the Jammu and Kashmir as a Tourist Destination. Journal of tourism studies and research in tourism, 18(18): Pp. 37-43.

http://www.revistadeturism.ro/rdt/article/view/277

6. Camille, (2018). Low-Cost Marketing Tools for Tourism Promotion, Accessed On 27 March 2020.

https://breaktheicemedia.com/low-cost-marke ting-tools-for-tourism-promotion/ 
7. Cohen, H. (2011). The marketing definition. Accessed On: 27 March 2020.

https://heidicohen.com/marketing-definition/

8. Crowel, H., Gribben, H. \& Loo, J. (2014), Travel content takes off on YouTube. Accessed on 28 March 2020.

https://www.thinkwithgoogle.com/consumer-i nsights/travel-content-takes-off-on-youtube/

9. Dagostino, E. (2020). The role of internet exchange in a world of network opportunities. Accessed on 28 March 2020.

https://www.ptc.org/2020/03/the-role-of-inter net-exchanges-in-a-world-of-network-oppor tunities/

10. Esu, B. B. \& Ebitu, E. (2010). Promoting an Emerging Tourism Destination, Global Journal of Management and Business Research, 10(1): 21-28.

https://journalofbusiness.org/index.php/GJMBR/ article/view/5

11. Forbes, (2018). Is YouTube an effective marketing tool? Accessed on 28 March 2020. Accessed on 28 March 2020.

https://www.forbes.com/sites/quora/2018/12/26/i s-youtube-an-effective-marketing-tool/\#c73 afce $1 \mathrm{bb} 38$

12. Gale, A. (2017). YouTube and the Tourism Industry. Accessed On 27 March 2020. http://digitalresources.nz/article/m6ZktMh

13. Gartrell, R. B. (1994). Destination Marketing for Convention and Visitor Bureaus. Kendell/Hunt Publishing Company. Iowa

14. Google Data, (2014). Travelers' Road to Decision. Accessed on 28 March 2020.

http://docplayer.net/10440-June-2014-the-20 14traveler-s-road-to-decision.html

15. Hasan, M. M. U., Rahman, M. A., \& Hossain M. K. (2015). Promotional Tools Used in Tourism Industry of Bangladesh. International J. of Engineering Technology, 3(5): 223-228.

https://studyres.com/doc/4498234/promotionaltools-used-in-tourism-industry-of-bangladesh

16. Hossain MA, Suchana JJ, and Avi MAR. (2020). Promoting Bangladesh tourism through the internet: theoretical perspectives and empirical evidence, Can. J. Bus. Inf. Stud., 2(5), 87-95.

https://doi.org/10.34104/cjbis.020.087095

17. Hossain MM. (2020). Influential factors of tourists' satisfaction in Bangladesh: evidence from selected tourism destinations at Cumilla region, Can. J. Bus. Inf. Stud., 2(4), 75-86. https://doi.org/10.34104/cjbis.020.075086

18. Hostingfacts, (2020). Internet stats: facts and figure. Accessed on 28 March 2020. https://hostingfacts.com/internet-facts-stats/

19. Jobber, D. \& Fahy, J. (2003). Foundations of marketing, McGraw-Hill: London

20. Kaushal, N. (2014). Travelers Consuming More than Ever Travel Videos Content on YouTube: A Good Sign for Travel Businesses. Accessed on 28 March 2020. https://www.pagetraffic.com/blog/travelers-co nsuming-more-than-ever-travel-videos-content on-youtube-a-good-sign-for-travel-busines ses/

21. Kemp, S. (2020). 3.8 billion People use social media. Accessed on 28 March 2020. https://wearesocial.com/blog/2020/01/digital-2 020-3-8-billion-people-use-social-media

22. Luis, G. S. (2019), Technology's impact on tourism marketing. Accessed On 27 March 2020.

https://business.inquirer.net/284564/technologysimpact-on-tourism-marketing

23. Martorell, V. \& Gabriel, (2002). The Internet as a Marketing Tool for Tourism in the Balearic. Island. Journal of Information Technology \& Tourism, 5, Pp. 91-104. https://doi.org/10.3727/109830502108751073

24. Middleton, V.T.C. \& Clarke, J. (2001). Marketing in Travel and Tourism. Butterworth Heinemann: Oxford. Pp. 487. https://doi.org/10.1177/004728758902700320

25. Morrison, A.M. (2013). Marketing and Managing Tourism Destinations Paperback. Routledge. Abingdon-on-Thames.

26. Picincu, A. (2018). The importance of marketing in tourism. Accessed on 27 March 2020.

https://bizfluent.com/how-8034313-promote-t ravel-agency-business.html 
27. Pitanatri, P. D. S. \& Pitana, I. G. (2016). Digital Marketing in Tourism: The More Global, the More Personal. International Tourism Conference Promoting Cultural \& Heritage Tourism. Udayana University. 01 September-03 September 2016.

28. Rahman, S. (2017). Tourism Destination Marketing Using Facebook as a Promotional Tool. J. of Humanities and Social Science, 22(2): Pp. 87-90. https://doi.org/10.9790/0837-2202018790

29. Rasmussen, M. (2017). YouTube Video Ads for Travel Marketers. Accessed on 28 March 2020.

https://www.sojern.com/blog/youtube-ads-tra vel-marketers-explained/

30. Sardar S, Hossain ME, Hossain MI, and Islam MS. (2020). Factors affecting visitor's satisfaction: an empirical study on the Paharpur Buddha Vihara, Naogaon, Rajshahi, Int. J. Manag. Account. 2(4), 61-73. https://doi.org/10.34104/ijma.020.061073

31. Shrigwin, T. (2019). The most effective marketing tools for tourism. Accessed On 27 March 2020.

https://www.bizeez.com/usesful-marketing-t ools/

32. Sofia, R. \& Brian, H. (2016). The Use of YouTube as a Tourism Marketing Tool. Travel and Tourism Research Association: Advancing Tourism Research Globally. Accessed on 05 May, 2020.

https://scholarworks.umass.edu/cgi/viewcontent. cgi?article $=1647 \&$ context $=$ ttra
33. Statista, (2020). Global YouTube advertising revenues 2017-2019. Accessed on 28 March 2020.

https://www.statista.com/statistics/289658/youtu be-global-net-advertising-revenuee/

34. Steeves, K. (2019). The Best YouTube Strategy for Travel Brands Accessed On 27 March 2020.

https://www.checkfront.com/the-business-be nefits-of-youtube

35. Techroadians, (2020). The benefits of internet marketing for tourism. Accessed On 27 March 2020.

http://techroadians.com/benefits-of-internet-m arketing-for-tourism/

36. Tsvetkov, T. (2019). YouTube Ads: The Ultimate Guide for Travel Marketers. Accessed on 28 March 2020.

https://pro.regiondo.com/youtube-ads-for-tra velmarketers/

37. UNWTO, (1999). Marketing Tourism Destinations Online: Strategies for the Information Age. Accessed On: 27 March 2020.

https://www.e-unwto.org/doi/book/10.18111/ 9789284403288

38. UNWTO. (2020). International Tourism Growth Continues to Outpace the Global Economy. Accessed on 27 March 2020. https://www.unwto.org/international-tourism-g rowth-continues-to-outpace-the-economy

39. White, R. (2019). Ways for Tourism Brands to Optimize YouTube. Accessed On: 27 March 2020.

https://tourismeschool.com/blog/tourism-mar keting-youtube/

Citation: Roy SK, Fatema MR, Islam MJ, and Huda MN. (2020). Reviewing YouTube as a compelling tool for the promotion of tourism, Int. J. Manag. Account. 2(5), 96-104. https://doi.org/10.34104/ijma.020.0960104 (9) क 